\title{
Assessment of Soil Health and Soil Quality of Kandhamal District, Odisha
}

\author{
Sushri Shainee Singh*, Narendra Swaroop and Tarence Thomas
}

Department of Soil Science and Agricultural Chemistry, Naini Agricultural Institute, Sam

Higginbottom University of Agriculture, Technology and Sciences, Prayagraj, U.P., India

*Corresponding author

\section{A B S T R A C T}

Keywords

Soil health, Soil quality, $\mathrm{pH}, \mathrm{EC}$, Sulphur, Zinc, Kandhamal, Soil

\section{Article Info}

Accepted:

15 December 2020

Available Online:

10 January 2021
Maintenance of soil health is prime importance for sustainable crop production. Soil quality is rapidly de-creasing in many regions around the world. There are many reasons leading to soil quality deterioration, including changes in land use types from forest to arable land and the con- sequences from intensive land use. In the present investigation analysis of different physical and chemical characteristics were made to determine soil health of Kandhamal district. Results show that soil bulk density was in normal range, soil particle density varied from 2.22 to $3.33 \mathrm{~g} \mathrm{~cm}^{-3}$, soil $\mathrm{pH}$ and EC were found to be acidic and non-saline in nature respectively while soil organic carbon and available phosphorus were in medium to high range. Available nitrogen and potassium were found to be low to medium range i.e., 198.82 to $385.6 \mathrm{Kg} \mathrm{ha}^{-1}$ and 82.23 to $167.6 \mathrm{Kg} \mathrm{ha}^{-1}$ respectively. Deficiency of sulphur followed by zinc was found in soils of Kandhamal district.

\section{Introduction}

Soils vary widely as a function of their position on the landscape and agricultural management, land use and cultivation intensity (Ayele et al., 2020). Soil quality is simply defined as "the capacity of a specific kind of soil "(Karlen et al., 1997), i.e., mainly to provide nutrition to plants and absorb and drain water. The different properties of soil are - texture, moisture, fertility (level of nitrogen, phosphorus, and potassium) and $\mathrm{pH}$ level, where the $\mathrm{pH}$ is the measure of a soil's acidity or alkalinity (Pham et al., 2018). Unfortunately, soil quality is rapidly decreasing in many regions around the world
(Vitousek, Mooney, Lubchenco, \& Melillo, 1997). There are many reasons leading to soil quality deterioration, including changes in land use types from forest to arable land (Oguike \& Mbagwu, 2009) and the consequences from intensive land use (Jamala \& Oke, 2013).

The present study was made to determine the health and quality of different soils collected from different villages of Kandhamal district. Different physical and chemical characteristics were analyzed to identify soil health related crop production constraints along with suggesting remedial measures for higher crop production. The colour of the soil 
is one of the most important indications of the pedogenic processes (soil forming processes) as well as moisture status of the soil (Digal et al., 2018). Soil organic matter accumulation improve SQ by decreasing bulk density (BD), surface sealing and crust formation (Mohanty et al., 2007), and by increasing aggregate stability (Somasundaram et al., 2013), cation exchange capacity, nutrient cycling, and biological activity (Karlen and Andrews, 2004). The most popular indicators used to assess soil quality are soil organic carbon (SOC), total nitrogen (TN) and soil acidity (pH) (Pham et al., 2018). SOC is fundamental to soil fertility and is a strong indicator of a soil's biological health (Chan et al., 2010) as well as its chemical, biological, and physical processes. TN is the main nutrient used for vegetation growth and is also used as a key soil quality assessment (Ren, Wang, Chen, Zhang, \& Lu, 2014). Soil $\mathrm{pH}$ is one of the most important soil parameters and essential for agricultural production. Most agricultural crops develop best in soil with a $\mathrm{pH}$ from 5.5 to 6.5 (Havlin, Beaton, Tisdale, \& Nelson, 1999).

\section{Materials and Methods}

\section{Experimental site}

Kandhamal district comes under North Eastern Ghat Agro Climatic Zone of Odisha (Nanda et al., 2008). As per modern system of soil classification "Soil Taxonomy" the soils of Kandhamal district are classified under the Alfisols, Inceptisols and Entisols (Sahu \& Mishra, 2005). It lies between $83^{\circ} 301 \mathrm{E}$ to $84^{\circ} 481 \mathrm{E}$ longitude and between $19^{\circ} 341 \mathrm{~N}$ to $20^{\circ} 541 \mathrm{~N}$. It has a total geographical area of $8021 \mathrm{Sq} \mathrm{Km}$ with an average annual rainfall of $1597 \mathrm{~mm}$ (62.9). The average minimum and maximum temperatures are $1^{\circ}$ in December to $35^{\circ} \mathrm{C}$ respectively (Jena et al., 2016).

\section{Soil sampling and analysis}

Soil samples were collected from two different depths $(0-15 \mathrm{~cm}$ and $15-30 \mathrm{~cm})$ of different villages of Balliguda, Nuagaon and Tumudibandha blocks of Kandhamal district of Odisha. From each block three different villages were selected for study. With the help of spade/garden hoe and khurpi soils were collected from crop fields by following vshaped method. Samples were dried in shade and large clods were broken using wooden mallet. Using $2 \mathrm{~mm}$ sieve the powdered soils were sieved and were collected in a clean cloth or polythene bag and was labeled properly for laboratory analysis. A total no. of eighteen soil samples were collected from nine different villages along with latitude and longitude of the collected site by using GPS.

Soil samples were analyzed for its colour (by using Munsell colour chart), bulk density and particle density by Core method and Graduated measuring cylinder method respectively (by Muthuvel et al., 1992 as described by Black, 1965), pH (1:2) (Jackson, 1958), EC (1:2) (Wilcox, 1950), organic carbon wet oxidation method (Walkley, 1947), available nitrogen by alkaline potassium permanganate method (Subbiah and Asija, 1956), available phosphorus by photoelectric colorimeter (Olson et al., 1954), available potassium by flame photometer (Toth and Prince, 1949), available zinc by DTPA method (Lindsay and Norvell, 1969).

\section{Results and Discussion}

\section{Soil colour}

In dry condition, the reflection of soil colour from soils of two depths (0-15 cm \& 15-30 $\mathrm{cm})$ of different villages of Kandhamal district varied from brownish yellow (10YR $6 / 6)$ colour to yellowish brown (7.5YR 5/8) colour. And in wet condition, the soil colour 
reflection varied from dark brown (10YR 3/3) colour to dark yellowish brown (10YR 4/4) colour. Variation in soil colour could be attributed to the varying water table in different land types (Digal et al., 2018). Similar findings have also been observed by Digal et al., (2018).

\section{Bulk density and particle density of soil}

No significant difference was found in bulk density due to depth and due to village. The bulk density of soils of different villages varied from 1.11 to $1.33 \mathrm{~g} \mathrm{~cm}^{-3}$. The maximum mean bulk density of $1.29 \mathrm{~g} \mathrm{~cm}^{-3}$ was found at $\mathrm{V}_{5}-$ Balipada village and the minimum mean bulk density of $1.15 \mathrm{~g} \mathrm{~cm}^{-3}$ was found at $V_{1}$ - Badeketa, $V_{2}-$ Budrukia, $\mathrm{V}_{4}-$ Nuagaon and $\mathrm{V}_{8}-$ Badagaon village. Increase in bulk density with depth was due to low organic matter and less aggregation. Similar findings were also reported by Sahoo et al., (2015).

Whereas in particle density, no significant difference was found due to depth while a significant difference was found between villages. The particle density of soils from different villages varied from 2.22 to $3.33 \mathrm{~g}$ $\mathrm{cm}^{-3}$. The maximum mean particle density of $3.1 \mathrm{~g} \mathrm{~cm}^{-3}$ was found at $\mathrm{V}_{1}-$ Badeketa, $\mathrm{V}_{4}-$ Nuagaon and $\mathrm{V}_{7}-$ Tumudibandha village and the minimum mean bulk density of $2.22 \mathrm{~g}$ $\mathrm{cm}^{-3}$ was found at $\mathrm{V}_{5}-$ Balipada village. Particle density of soil was found to be in the range of medium to dense. Particle density varies according to the mineral content of the soil particles.

\section{Soil reaction}

Significant difference was found in soil $\mathrm{pH}$ due to depth and due to village. The soil $\mathrm{pH}$ of different villages varied between 4 to 5.7. The maximum mean $\mathrm{pH}$ of 5.5 was found at $\mathrm{V}_{5}$ - Balipada village and the minimum mean
$\mathrm{pH}$ of 4.2 was found at $\mathrm{V}_{7}-$ Tumudibandha village.

Hence, the soil acidity appears to be a major crop production constraint in the study area (Digal et al., 2018). Similar findings have also been reported earlier by Mishra et al., (2014), Jena et al., (2016), Subnudhi and Subudhi (2017) and Digal et al., (2018).

\section{Electrical Conductivity $\left(\mathrm{dS} \mathbf{~ m}^{-1}\right)$}

Significant difference was found in electrical conductivity in soils due to depth and due to village. The soil EC at two depths of different villages varied between 0.1 to $0.23 \mathrm{dS} \mathrm{m}$. The maximum mean EC of $0.22 \mathrm{dS} \mathrm{m}^{-1}$ was found at $V_{1}-$ Badeketa village and the minimum mean EC of $0.03 \mathrm{dS} \mathrm{m}^{-1}$ was found at $\mathrm{V}_{6}-$ Kanjamendi and $\mathrm{V}_{9}-$ Batabadi village. Soils of the study area were found to be nonsaline in nature. Hence, all the soils under the study area are safe for all types of crop production with respect to the soluble salt content (Digal et al., 2018). Similar findings have also been reported earlier by Mishra et al., (2014), Jena et al., (2016) and Digal et al., (2018).

\section{Organic carbon}

A significant difference was found in organic carbon content in soils due to depth whereas no significant difference was found in organic carbon content in soils between villages. Soil organic carbon content in soils of different villages varied between 0.54 to $1.25 \%$. The highest mean soil organic carbon content was found at $\mathrm{V}_{3}$-Lankamunda $(0.94 \%)$ and lowest mean soil organic carbon content was found at $\mathrm{V}_{7}$ - Tumudibandha $(0.56 \%)$. Soil organic carbon status was found to be medium to high which enables the soil for higher crop production. Medium to higher organic carbon in the study area could be attributed to its presence in the bottom of 
dense forest (Digal et al., 2018). Similar findings have also been reported by Mishra $e t$ al., (2014), Jena et al., (2016), Subnudhi and Subudhi (2017) and Digal et al., (2018).

\section{Available nitrogen}

A significant difference was found in available nitrogen in soils due to depth and due to village. Availability of nitrogen content in soils of different villages varied between 198.82 to $385.6 \mathrm{Kg} \mathrm{ha}^{-1}$. The highest mean available nitrogen was found at $\mathrm{V}_{2}$-Budrukia $\left(318.85 \mathrm{Kg} \mathrm{ha}^{-1}\right)$ and lowest mean available nitrogen was found at $\mathrm{V}_{9}-$ Batabadi $\left(208.81 \mathrm{Kg} \mathrm{ha}^{-1}\right)$. The available nitrogen status in the entire study area was found to be low to medium. The reason may be attributed to the fact that nitrogen content is positively correlated with organic matter content which decreases with depth. Similar findings have also been reported by Mishra et al., (2014), Dash et al., (2018) and Digal et al., (2018).

Table.1 Soil sampling sites

\begin{tabular}{|c|c|}
\hline Block & Village \\
\hline \multirow{3}{*}{ Balliguda $\left(\mathrm{B}_{1}\right)$} & $\operatorname{Badeketa}\left(\mathrm{V}_{1}\right)$ \\
\hline & Budrukia $\left(\mathrm{V}_{2}\right)$ \\
\hline & Lankamunda $\left(\mathrm{V}_{3}\right)$ \\
\hline \multirow{3}{*}{ Nuagaon $\left(B_{2}\right)$} & Nuagaon $\left(V_{4}\right)$ \\
\hline & Balipada $\left(V_{5}\right)$ \\
\hline & Kanjamendi $\left(\mathrm{V}_{6}\right)$ \\
\hline \multirow[t]{3}{*}{ Tumudibandha $\left(\mathrm{B}_{3}\right)$} & Tumudibandha $\left(\mathrm{V}_{7}\right)$ \\
\hline & Badagan $\left(V_{8}\right)$ \\
\hline & Batabadi $\left(V_{9}\right)$ \\
\hline
\end{tabular}

Table.2 Bulk density and particle density in soils of different villages of Kandhamal District at two different depths

\begin{tabular}{|c|c|c|c|c|c|c|}
\hline \multirow[t]{2}{*}{ Village } & \multicolumn{3}{|c|}{ Bulk density $\left(\mathrm{g} \mathrm{cm}^{-3}\right)$} & \multicolumn{3}{|c|}{ Particle density $\left(\mathrm{g} \mathrm{cm}^{-3}\right)$} \\
\hline & $0-15 \mathrm{~cm}$ & $15-30 \mathrm{~cm}$ & Mean & $0-15 \mathrm{~cm}$ & $15-30 \mathrm{~cm}$ & Mean \\
\hline$V_{1}$ & 1.11 & 1.18 & 1.15 & 2.86 & 3.33 & 3.1 \\
\hline $\mathbf{V}_{2}$ & 1.11 & 1.18 & 1.15 & 2.5 & 2.86 & 2.68 \\
\hline $\mathbf{V}_{\mathbf{3}}$ & 1.18 & 1.25 & 1.22 & 2.5 & 2.22 & 2.36 \\
\hline $\mathbf{V}_{4}$ & 1.11 & 1.18 & 1.15 & 2.86 & 3.33 & 3.1 \\
\hline $\mathbf{V}_{5}$ & 1.25 & 1.33 & 1.29 & 2.22 & 2.22 & 2.22 \\
\hline$V_{6}$ & 1.18 & 1.18 & 1.18 & 2.5 & 2.5 & 2.5 \\
\hline $\mathbf{V}_{7}$ & 1.18 & 1.25 & 1.22 & 2.86 & 3.33 & 3.1 \\
\hline $\mathbf{V}_{8}$ & 1.11 & 1.18 & 1.15 & 2.5 & 2.86 & 2.86 \\
\hline$V_{9}$ & 1.18 & 1.25 & 1.22 & 2.5 & 2.22 & 2.36 \\
\hline Mean & 1.16 & 1.22 & & 2.59 & 2.76 & \\
\hline & F-test & $\operatorname{SEm}( \pm)$ & CD at $5 \%$ & F-test & $\operatorname{SEm}( \pm)$ & CD at $5 \%$ \\
\hline Due to depth & NS & 0.032 & - & NS & 0.785 & 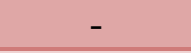 \\
\hline Due to village & NS & 0.017 & - & $\mathrm{S}$ & 0.116 & 0.020 \\
\hline
\end{tabular}


Table.3 Soil pH and Electrical conductivity (EC) in soils from different villages of Kandhamal District at two different depths

\begin{tabular}{|c|c|c|c|c|c|c|}
\hline \multirow[t]{2}{*}{ Village } & \multicolumn{3}{|c|}{ pH } & \multicolumn{3}{|c|}{$E C\left(d S m^{-1}\right)$} \\
\hline & $0-15 \mathrm{~cm}$ & $15-30 \mathrm{~cm}$ & Mean & $0-15 \mathrm{~cm}$ & $15-30 \mathrm{~cm}$ & Mean \\
\hline $\mathbf{V}_{1}$ & 4.3 & 4.7 & 4.5 & 0.23 & 0.2 & 0.22 \\
\hline $\mathbf{V}_{2}$ & 4.3 & 4.8 & 4.6 & 0.16 & 0.13 & 0.15 \\
\hline $\mathbf{V}_{3}$ & 4.4 & 4.8 & 4.6 & 0.05 & 0.03 & 0.04 \\
\hline $\mathbf{V}_{4}$ & 4.6 & 4.9 & 4.8 & 0.18 & 0.16 & 0.17 \\
\hline$V_{5}$ & 5.7 & 5.33 & 5.5 & 0.14 & 0.12 & 0.13 \\
\hline $\mathbf{V}_{6}$ & 4.5 & 4.9 & 4.7 & 0.04 & 0.02 & 0.03 \\
\hline $\mathbf{V}_{7}$ & 4 & 4.4 & 4.2 & 0.11 & 0.1 & 0.11 \\
\hline $\mathbf{V}_{8}$ & 4.1 & 4.5 & 4.3 & 0.06 & 0.05 & 0.06 \\
\hline $\mathbf{V}_{9}$ & 4 & 4.5 & 4.3 & 0.04 & 0.02 & 0.03 \\
\hline \multirow[t]{2}{*}{ Mean } & 4.4 & 4.8 & & 0.11 & 0.09 & \\
\hline & F-test & $\operatorname{SEm}( \pm)$ & CD at $5 \%$ & F-test & $\operatorname{SEm}( \pm)$ & CD at $5 \%$ \\
\hline Due to depth & S & 0.163 & 0.007 & $S$ & 0.01 & 0.00003 \\
\hline Due to village & S & 0.132 & 0.003 & S & 0.023 & 0.000000002 \\
\hline
\end{tabular}

Table.4 Soil organic carbon in soils of different villages of Kandhamal District at two different depths

\begin{tabular}{|c|c|c|c|}
\hline \multirow[t]{2}{*}{ Village } & \multicolumn{3}{|c|}{ Soil Organic carbon $(\%)$} \\
\hline & $0-15 \mathrm{~cm}$ & $15-30 \mathrm{~cm}$ & Mean \\
\hline $\mathbf{V}_{1}$ & 0.83 & 0.62 & 0.73 \\
\hline $\mathbf{V}_{2}$ & 0.85 & 0.67 & 0.76 \\
\hline $\mathbf{V}_{3}$ & 1.25 & 0.62 & 0.94 \\
\hline $\mathbf{V}_{4}$ & 0.68 & 0.6 & 0.64 \\
\hline $\mathbf{V}_{5}$ & 0.69 & 0.66 & 0.68 \\
\hline $\mathbf{V}_{6}$ & 0.72 & 0.59 & 0.66 \\
\hline $\mathbf{V}_{7}$ & 0.57 & 0.54 & 0.56 \\
\hline $\mathbf{V}_{8}$ & 0.67 & 0.64 & 0.66 \\
\hline $\mathbf{V}_{9}$ & 0.67 & 0.62 & 0.65 \\
\hline \multirow[t]{2}{*}{ Mean } & 0.77 & 0.62 & \\
\hline & F-test & $\operatorname{SEm}( \pm)$ & CD at $5 \%$ \\
\hline Due to depth & $S$ & 0.076 & 0.044 \\
\hline Due to village & NS & 0.036 & - \\
\hline
\end{tabular}


Table.5 Available nitrogen, phosphorus and potassium in soils of different villages of Kandhamal District at two different depths

\begin{tabular}{|c|c|c|c|c|c|c|c|c|c|}
\hline \multirow[t]{2}{*}{ Village } & \multicolumn{3}{|c|}{$\begin{array}{l}\text { Available Nitrogen } \\
\left(\mathrm{Kg} \mathrm{ha}^{-1}\right)\end{array}$} & \multicolumn{3}{|c|}{$\begin{array}{l}\text { Available Phosphorus } \\
\left(\mathrm{Kg} \mathrm{ha}^{-1}\right)\end{array}$} & \multicolumn{3}{|c|}{$\begin{array}{c}\text { Available Potassium } \\
\left(\mathrm{Kg} \mathrm{ha}^{-1}\right)\end{array}$} \\
\hline & $\begin{array}{l}0-15 \\
\text { cm }\end{array}$ & $15-30 \mathrm{~cm}$ & Mean & $\begin{array}{l}0-15 \\
\text { cm }\end{array}$ & $\begin{array}{c}15-30 \\
\text { cm }\end{array}$ & Mean & $\begin{array}{l}0-15 \\
\mathrm{~cm}\end{array}$ & $15-30 \mathrm{~cm}$ & Mean \\
\hline$V_{1}$ & 330 & 262.6 & 296.3 & 53.1 & 50.26 & 51.68 & 161.6 & 96.47 & 129.04 \\
\hline $\mathbf{V}_{2}$ & 385.6 & 252.1 & 318.85 & 54.8 & 51.42 & 53.11 & 100.6 & 89 & 94.8 \\
\hline $\mathbf{V}_{3}$ & 322.05 & 252.1 & 287.08 & 45.56 & 42.81 & 44.19 & 101.7 & 86.42 & 94.06 \\
\hline$V_{4}$ & 278.33 & 232.12 & 255.23 & 26.7 & 24.16 & 25.43 & 167.6 & 99.33 & 133.47 \\
\hline$V_{5}$ & 266.4 & 260.7 & 263.55 & 27.32 & 24.22 & 25.77 & 134.1 & 122.5 & 128.3 \\
\hline$V_{6}$ & 224.5 & 208.78 & 216.64 & 22.32 & 20.84 & 21.73 & 100.3 & 90.55 & 95.43 \\
\hline $\mathbf{V}_{7}$ & 262.6 & 252.1 & 257.35 & 25.4 & 24.7 & 24.12 & 101.3 & 96.75 & 99.03 \\
\hline $\mathbf{V}_{8}$ & 222.6 & 206.9 & 214.75 & 22.6 & 20.34 & 21.3 & 112.2 & 93.2 & 102.7 \\
\hline $\mathbf{V}_{9}$ & 218.8 & 198.82 & 208.81 & 21.34 & 18.76 & 19.89 & 121.2 & 82.23 & 101.72 \\
\hline \multirow[t]{2}{*}{ Mean } & 278.99 & 236.25 & & 37.4 & 34.2 & & 122.29 & 95.16 & \\
\hline & F-test & $\operatorname{SEm}( \pm)$ & $\begin{array}{c}\text { CD at } \\
5 \%\end{array}$ & F-test & $\operatorname{SEm}( \pm)$ & CD at $5 \%$ & F-test & $\operatorname{SEm}( \pm)$ & CD at $5 \%$ \\
\hline $\begin{array}{l}\text { Due to } \\
\text { depth }\end{array}$ & S & 21.37 & 0.015 & S & 1.20 & 0.00003 & S & 13.56 & 0.010 \\
\hline $\begin{array}{l}\text { Due to } \\
\text { village }\end{array}$ & S & 12.94 & 0.05 & S & 4.53 & 0.00000000003 & NS & 5.49 & - \\
\hline
\end{tabular}

Table.6 Available zinc and sulphur in soils of different villages of Kandhamal District at two different depths

\begin{tabular}{|c|c|c|c|c|c|c|}
\hline \multirow[t]{2}{*}{ Village } & \multicolumn{3}{|c|}{ Available Zinc (ppm) } & \multicolumn{3}{|c|}{ Available Sulphur (ppm) } \\
\hline & $0-15 \mathrm{~cm}$ & $15-30 \mathrm{~cm}$ & Mean & $0-15 \mathrm{~cm}$ & $15-30 \mathrm{~cm}$ & Mean \\
\hline $\mathbf{V}_{1}$ & 0.37 & 0.56 & 0.47 & 2.77 & 3.7 & 3.24 \\
\hline $\mathbf{V}_{2}$ & 0.58 & 0.33 & 0.46 & 0.37 & 0.18 & 0.28 \\
\hline $\mathbf{V}_{\mathbf{3}}$ & 0.35 & 0.18 & 0.27 & 2.59 & 2.77 & 2.68 \\
\hline $\mathbf{V}_{4}$ & 0.4 & 0.85 & 0.63 & 3.7 & 2.22 & 2.96 \\
\hline$V_{5}$ & 0.37 & 0.59 & 0.48 & 2.96 & 2.4 & 2.68 \\
\hline$V_{6}$ & 0.59 & 0.77 & 0.68 & 2.59 & 2.75 & 2.67 \\
\hline $\mathbf{V}_{7}$ & 0.33 & 0.59 & 0.46 & 3.7 & 2.59 & 3.15 \\
\hline$V_{8}$ & 0.96 & 0.4 & 0.68 & 2.96 & 2.4 & 2.68 \\
\hline$V_{9}$ & 0.7 & 0.22 & 0.46 & 3.34 & 2.22 & 2.78 \\
\hline Mean & 0.52 & 0.5 & & 2.78 & 2.36 & \\
\hline & F-test & $\operatorname{SEm}( \pm)$ & CD at $5 \%$ & F-test & $\operatorname{SEm}( \pm)$ & CD at $5 \%$ \\
\hline Due to depth & NS & 0.009 & - & NS & 0.208 & - \\
\hline Due to village & NS & 0.044 & - & $\mathrm{S}$ & 0.295 & 0.014 \\
\hline
\end{tabular}

\section{Available phosphorus}

A significant difference was found in available phosphorus in soils due to depth and due to village. Availability of phosphorus content in soils of different villages varied between 20.34 to $54.11 \mathrm{Kg} \mathrm{ha}^{-1}$. The highest mean available phosphorus was found at $\mathrm{V}_{2}-$ 
Budrukia $\left(53.11 \mathrm{Kg} \mathrm{ha}^{-1}\right)$ and lowest mean available phosphorus was found at $\mathrm{V}_{8}-$ Badagan $\left(21.3 \mathrm{Kg} \mathrm{ha}{ }^{-1}\right)$. The available phosphorus status in the entire study area was found to be medium to high. Similar findings have also been reported by Mishra et al., (2014), Dash et al., (2018) and Digal et al., (2018).

\section{Available potassium}

A significant difference was found in available potassium in soils due to depth and no significant difference was found in available potassium in soils between villages. Availability of potassium content in soils of different villages varied between 82.23 to 167.6 $\mathrm{Kg} \mathrm{ha}^{-1}$. The highest mean available potassium was found at $\mathrm{V}_{4}-$ Nuagaon $\left(133.47 \mathrm{Kg} \mathrm{ha}^{-1}\right)$ and lowest mean available potassium was found at $\mathrm{V}_{3}$-Lankamunda $\left(94.06 \mathrm{Kg} \mathrm{ha}^{-1}\right)$.

The available potassium status in the entire study area was found to be low to medium. The highest $\mathrm{K}$ content observed in the surface horizon and showed more or less decreasing trend with depth. This might be attribute to more intense weathering and release of liable $\mathrm{K}$ from organic residues. Similar findings have also been reported by Mishra et al., (2014), Dash et al., (2018) and Digal et al., (2018).

\section{Available zinc}

No significant difference was found in available zinc in soils due to depth and due to village. Availability of zinc in soils of different villages at two different depths varied from 0.18 to $0.96 \mathrm{ppm}$. The highest mean available zinc was found at $\mathrm{V}_{6}$ Kanjamendi and $\mathrm{V}_{8}$ - Badagan (0.68 ppm) and lowest mean available zinc was found at $\mathrm{V}_{3}$ Lankamunda $(0.27 \mathrm{ppm})$. Zn deficiency was observed in all blocks of the district (Jena et al., 2016). Similar result was reported by Jena et al., (2016).

\section{Available sulphur}

No significant difference was found in available zinc in soils due to depth while a significant difference was found in available zinc in soils between villages. Availability of sulphur content in soils varied from 0.18 to $3.7 \mathrm{ppm}$. The highest mean available sulphur was found at $\mathrm{V}_{1}$ - Badeketa (3.24 ppm) and lowest mean available sulphur was found at $\mathrm{V}_{2}$-Budrukia (0.28 ppm).

High deficiency of $\mathrm{S}$ in Kandhamal soils might be attributed to high altitude upland (Alfisols) leading to leaching of anionic nutrients (Jena et al., 2016). Available sulphur was found to be in the range of low to medium (Digal et al., 2018). Similar results were observed by Mishra et al., (2014) Jena et al., (2016) and Digal et al., (2018).

Above data shows that the physical properties like soil colour and bulk density are within normal range of parameters. Particle density of soils was found to be medium to dense. Whereas $\mathrm{pH}$ value of soil samples shows that most of them are acidic in nature and soil EC value shows that most of them are is of nonsaline in nature. The soil organic carbon and available phosphorus content of these soils were found to be medium to high whereas available nitrogen and available potassium content in these soils were found to be low to medium. Zinc deficiency was observed in these soils. The available sulphur in these soils were found to be in low to medium range.

Therefore 25 percent more nitrogenous and potassic fertilizers should be applied than that of the recommended dose of the same in the fields having lower range of nitrogen and potassium status and 25 percent less 
phosphatic fertilizers should be applied than that of the recommended dose of the same in those fields having higher in potassium status. Since most soils show sulphur and zinc deficiency, 25 percent more zinc and sulphur containing fertilizers should be applied than that of the recommended dose of the same in those fields having lower range of zinc and sulphur status.

In conclusion the major crop production constraint in the study area was found to be soil acidity. Due to soil erosion and water logging, most of the soils were found to be deficient in available nitrogen, potassium, zinc and sulphur content. So, application of liming materials along with application of soil test based nitrogenous, potassic, zinc and sulphur containing fertilizers and manures will help to obtain higher crop production as well as sustaining soil health.

Hence, it is concluded that to obtain better soil health and soil quality a more attention is needed to pay in the role of macronutrient enhancement in the soil which will lead to optimum economic yield. And for maintaining soil health and soil quality adoption of organic farming will be an essential step.

\section{References}

Anonymous (1971) Munsell Soil Colour Chart, Munsell Color Company Inc., 2441 N, Calvert Street, Baltimore, Maryland 21212, USA.

Ayele, G. T., Demissie, S. S., Jemberrie, M. A., Jeong, J and Hamilton, D. P. (2020) Terrain effects on the spatial variability of soil physical and chemical properties, Soil Systems, 4, 1

Black, C.A. (1965) Methods of Soil Analysis, Vol. 1, American Society of Agronomy, Madison, Wisconsin, USA.

Chan, K. Y., Oates, A., Liu, D. L., Prangnell,
R., Poile, G., \& Conyers, M. K. (2010) A farmer's guide to increasing soil organic carbon under pastures. Wagga Wagga, NSW: Industry and Investment NSW

Dash PK, Mishra A, Saren S, Revathi B and Sethy SK. (2018)Preparation of GPS and GIS Based Soil Fertility Maps and Identification of Soil Related Crop Production Constraints of RRTTS and KVK Farm, Dhenkanal Located in the Mid-Central Table Land Agro Climatic Zone of Odisha, India, International Journal of Chemical Studies, Vol. 6(5), Pg: 934-943.

Digal, M., Saren, S., Mishra, A., Dash, P.K., Swain, N. and Acharya, B.P. (2018) Soil fertility status of some villages in Phiringia block of Kandhamal district under North-Eastern Ghat agro climatic zone of Odisha, India, Journal of Pharmacognosy and Phytochemistry, Vol. 7(6), pp. 658-662.

Havlin, J. L., Beaton, J. D., Tisdale, S. L., \& Nelson, W. L. (1999) Soil fertility and fer- tilizers: An introduction to nutrient management, USA: Prentice-Hall Inc.

Jackson, M. L. (1958) Soil Chemical Analysis, Prentice - Hall India, New Delhi.

Jamala, G.Y., \& Oke, D.O. (2013) Soil profile characteristics as affected by land use systems in The Southeastern Adamawa State, Nigeria. Journal of Agriculture and Veterinary Science, Vol. 6(4), pp. 04-11.

Jena, B., Nayak, R.K., Das, J., Parida, R.K. and Sethi, D. (2016) Secondary and micro nutrient mapping in forest soils of Kandhamal district, Odisha, Agropedology, Vol. 26 (01), pp. 79-86.

Karlen, D. L., \& Andrews, S. S. (2004). Soil quality, fertility, and health-Historical context, status and perspectives, In Schjønning P et al., (ed.) Managing soil quality: Challenges in modern 
agriculture, CABI Int. Publ., Oxon, UK. pp. 17-33.

Karlen, D. L., Mausbach, M. J., Doran, J. W., Cline, R. G., Harris, R. F., \& Schuman, G. E. (1997) Soil quality: A concept, definition, and framework for evaluation, Soil Science Society of America Journal, Vol. 61(1), pp. 4-10.

Lindsay, M. L., and Norvell, W.A. (1969) Equilibrium relationship of $\mathrm{Zn}^{2+}, \mathrm{Fe}^{2+}$, $\mathrm{Ca}^{2+}$ and $\mathrm{H}^{+}$with EDTA and DTPA in soils, Soil Science Society of America Journal, Vol. 35, pp. 62-68.

Mishra, A., Pattnaik, T., Das, D. and Das, M.(2014) Soil fertility maps preparation using GPS and GIS in Dhenkanal District, Odisha, India, International Journal of Plant \& Soil Science, Vol.3(8), Pg: 986-994.

Mohanty. M., Painuli, D. K., Misra. A. K., Ghosh, P. K., (2007) Soil quality effects of tillage and residue under rice-wheat cropping on a vertisol in India, Soil \& Tillage Research Journal, Vol. 92, pp. 243-250.

Nanda S. K., Mishra, A., Pradhan, N. K., Muralidharudu, Y. (2008) Soil testing and fertilizer recommendation in Odisha, AICRP on Soil Test Crop Response, Department of Soil Science and Agricultural Chemistry, OUAT, BBSR.

Oguike, P. C., \& Mbagwu, J. S. C. (2009) Variations in some physical properties and organic matter content of soils of coastal plains and under different land use type, World Journal of Agricultural Sciences, Vol. 5(1), pp. 63-69.

Olsen, S. R., Cole, C. V., Watnahe, F. S. and Dean, L. A. (1954) Estimation of available phosphorus in soils by extraction with sodium bicarbonate, U. S. Department of Agriculture Circular, No. 939.

Pham, T. G., Nguyen, H. T., Kappas, M. (2018) Assessment of soil quality indicators under different agricultural land uses and topographic aspects in Central Vietnam, International Soil and Water Conservation Research, Vol. 6, pp. 280-288

Ren, T., Wang, J., Chen, Q., Zhang, F., \& Lu, S. (2014) The effects of manure and nitrogen fertilizer applications on soil organic carbon and nitrogen in a highinput cropping system, PLoS One, Vol. 9(5).

Sahoo, H.K., Behera, B., Behera, U.K. and Das, T.K. (2015) Land productivity enhancement and soil health improvement in rainfed rice (Oryza sativa) farms of Odisha through integrated farming system, Indian Journal of Agronomy, Vol.-60(4), Pg: 485-492.

Sahu, G. C., \& Mishra, A. (2005) Soils of Orissa and their management, Orissa Review, Vol. LXII(4), pp. 56-60.

Sinha, N. K., Mohanty, M., Meena, B. P., Das, H., Chopra, U. K. and Singh, A. K. (2014) Soil quality indicators under continuous cropping systems in the arid ecosystem of India, African Journal of Agricultural Research, Vol. 9(2), pp. 285-293

Somasundaram, J., Singh, R. K., Ali, S., Sethy, B. K., Singh, D., Lakaria, B. L., Chaudhary, R. S., Singh, R. K., Sinha, N. K. (2013). Soil aggregates and other properties as influenced by different long term land uses under table landscape topography of Chambal region, Rajasthan, India, Journal of Agricultural Physics, Vol. 40, pp. 212217.

Subbiah, B. V. and Asija, C. L. (1956) A rapid procedure for the estimation of available nitrogen in soils, Current Science, Vol. 25, Pg: 259-260.

Subnudhi, C.R. and Subudhi, R. (2017) Soil and water conservation measures in degraded watershed of Kandhamal 
district, Odisha, International Journal Environmental Sciences \& Natural Resources, Mini review, Vol. - 2 Issue 4, IJESNR.MS.ID.555593.

Toth, S. J. and Prince, A. L. (1949) Estimation of cation exchange capacity and exchangeable $\mathrm{Ca}, \mathrm{K}$ and $\mathrm{Na}$ content of soil by flame photometer technique, Soil Science Journal, Vol. 67, pp. 439445.

Vitousek, P. M., Mooney, H. A., Lubchenco, J., \& Melillo, J. M.(1997) Human domination of earth's ecosystems,
Science Journal, Vol. 277(5325), pp. 494-499.

Walkley, A. (1947) Critical examination of rapid method for determining organic carbon in soils, effect of variation in digestion conditions and of inorganic soil constituents, Soil Science, Vol. 632, pp.: 251.

Wilcox L. V. (1950) Electrical Conductivity, America Water Works Association journal, Vol. 42, pp. 775-776.

\section{How to cite this article:}

Sushri Shainee Singh, Narendra Swaroop and Tarence Thomas. 2021. Assessment of Soil Health and Soil Quality of Kandhamal District, Odisha. Int.J.Curr.Microbiol.App.Sci. 10(01): 2501-2510. doi: https://doi.org/10.20546/ijcmas.2021.1001.290 